\title{
THE PECULIARITIES OF ACTINIDIA SPECIES LEAVES MICROMORPHOLOGY
}

\section{Motyleva Svetlana*, Kozak Nataliya,Kulikov Ivan, Medvedev Sergei, Imamkulova Zulfira}

Federal state budgetary scientific institution "All-Russian Horticultural Institute for Breeding, Agrotechnology and Nursery" (ARHIBAN), Moscow, Russia

The peculiarities of micromorphology of 4 species and 9 breeds of actinidia leaves from the collector plantations of FSBSI ARHIBAN are visualized via scanning electronic microscopy method. The comparative analysis of micro-sculptural and quantitative morphological characteristics was performed. Species and cultivars differences of Actinidia Lindley leaves are determined. The cells of actinidia adaxial side of leaves have similar irregular polyangular, lengthened, rarely oval form. Actinidia arguta (Siebold ex Zucc.) Planch. ex Miq. and Actinidia polygama (Siebold ex Zucc.) Maxim. have flexuous, irregular polyangular, rarely oval one. Actinidia purpurea Rehd. representatives have the cells of greatly polyangular and slightly flexuous form. Actinidia kolomikta (Maxim. ex Rupr.) Maxim. cells are greatly flexuous, in the space between the ribs on the both leaf sides flat trichomes are determined which consist of 2-3 members. The perimeter and the ratio of leaves length to their width of Actinidia kolomikta leaf abaxial side is close to the adaxial side ones. To determine the perimeter of Actinidia arguta, Actinidia purpurea and Actinidia polygama abaxial side cells is difficult due to the solid waxy layer. The minimum stomatal length is characteristic for Actinidia polygama $(9.73 \mu \mathrm{m})$, the maximal one is at Actinidia arguta and Actinidia purpurea (15.54 and $16.11 \mu \mathrm{m}$ respectively). All 4 actinidia species possess short trichomes along the primary rib. For Actinidia kolomikta in comparison with the rest species more lengthened cells form of the leaf adaxial side $(I / h=1.96)$ is characteristic. In majority cases the substantial differences in the stomatal number between male and female forms are not found.

Keywords: Actinidia; genetic collection; specie; breed; leaf; scanning electronic microscopy

\section{Introduction}

Actinidia is a perennial deciduous twining fruit liana. Mature fragrant fruit have a pleasant sour-sweet taste and fine texture. Actinidia fruit are full of a great number of biologically active substances including vitamin C (Мотылева и др., 2014). In ARHIBAN in the village Mikhnevo, Moscovskaya region, the organized collection of rare actinidia fruit lianas (Actinidia Lindley) consists of 167 samples of 3 species, which grow in the Far East of Russia: Actinidia kolomikta (Maxim. ex Rupr.) Maxim., Actinidia arguta (Siebold ex Zucc.) Planch. ex Miq., Actinidia polygama (Siebold ex Zucc.) Maxim. and 5 samples of introduced from China Actinidia purpurea Rehd., together with 20 hybrid forms of this specie together with Actinidia arguta (Козак и Колбасина, 2014; Козак, 2015).

*Corresponding author: Svetlana Motyleva, Federal state budgetary scientific institution "All-Russian Horticultural Institute for Breeding, Agrotechnology and Nursery" (ARHIBAN), Moscow, Russia, $₫$ motyleva_svetlana@mail.ru 
The purpose of the present researches is the comparative evaluation of qualitative and quantitative morphometric characteristics of actinidia collection samples leaves.

\section{Materials and methodology}

The experimental researches are performed in the laboratory of FSBSI ARHIBAN Plants genofond and bioresources center, (Mikhnevo, Moscovskaya region). The actinidia samples from genetic collection were studied (Козак, 2015). The researches were performed within 2013-2015.

The research objects were actinidia 4 species leaves: Actinidia kolomikta (the breeds of pistillate (female) type Prelestnaya, Prazdnichnaya, Nadezhda, Sestra, Priusadebnaya and the pollinating (male) variety Sakhar-Medovich), Actinidia arguta (the breeds of pistillate type - Zolotaya kosa, Doch' Zei and the pollinating variety Syn Zei); Actinidia polygama (the breeds of pitillate type - Zlata, Lesnaya, Perchik, Solntselikaya and the pollinating varieties Aurel, Blondin, Brunet); Actinidia purpurea (the pollinating variety Konsul and the pistillate type SPS-2). The samples preparations for the research were performed using the methods described in the works (Барыкина и др., 2004; Бисерова, 2013). The pieces of the lamina middle third located in the center between the leaf edge and the primary rib (to the left or to the right of the rib) were studied. The following morphological characteristics were examined: the epidermis cells form; the waxy layer character; the folding of the leaf adaxial side; the folds on the leaf abaxial side; the presence (absence) of the trichomes; the cells perimeter of the leaf adaxial side (it was measured along the outline with 300-600 zooming); the ratio of the leaf adaxial and abaxial sides cells length to their width (it was calculated after the corresponding parameters measurements); the number of stomatos on $1 \mathrm{~mm}^{2}$ (it was counted in microscope vision on $300 \times$ or 500x zooming); the stomatos length (it was determined according to the measurements). The measurements were repeated 100 times (not less than on 10 microscope fields, on the cuttings from not less than 10 leaves) with the average value calculation. The statistic processing was performed via Microsoft Excel.

The comparative-morphological studying of epidermis cells of the leaf adaxial and abaxial sides and the stomatal mechanism was performed according to the working rules on the scanning electron microscope JSM 600 LA by JEOL company (Japan) on conditions of the low vacuum ( $P=40-60 \mathrm{~Pa}$ ) on 150-700 and 2,000 zooming for the leaf adaxial side and 150-800 and 2,500 one for the leaf abaxial side.

\section{Results and discussion}

The figure, the leaf epidermis microsculpture, the cells form, the trichomes, strands and foldings presence, the stomatos location have specific and characteristic features for each plant species and breed and are the diagnostic features which can help to solve a lot of questions of systematics, ecology, physiology, and plants identity (Васильев и др., 1978; Паутов и др., 2002). The cells of actinidia leaves adaxial side have similar irregular polyangular, lengthened, rarely oval form. Actinidia arguta and Actinidia polygama have flexuous, irregular polyangular, rarely oval one. Actinidia purpurea representatives have the cells of greatly polyangular and slightly flexuous form. Actinidia kolomikta cells are greatly flexuous, in the space between the ribs on the both leaf sides flat trichomes are determined which consist of 2-3 members. All 4 actinidia species possess short trichomes along the primary rib. The waxy layer is solid and smooth (Figure 1). The quantitative morphometric features are given in Table 1. 

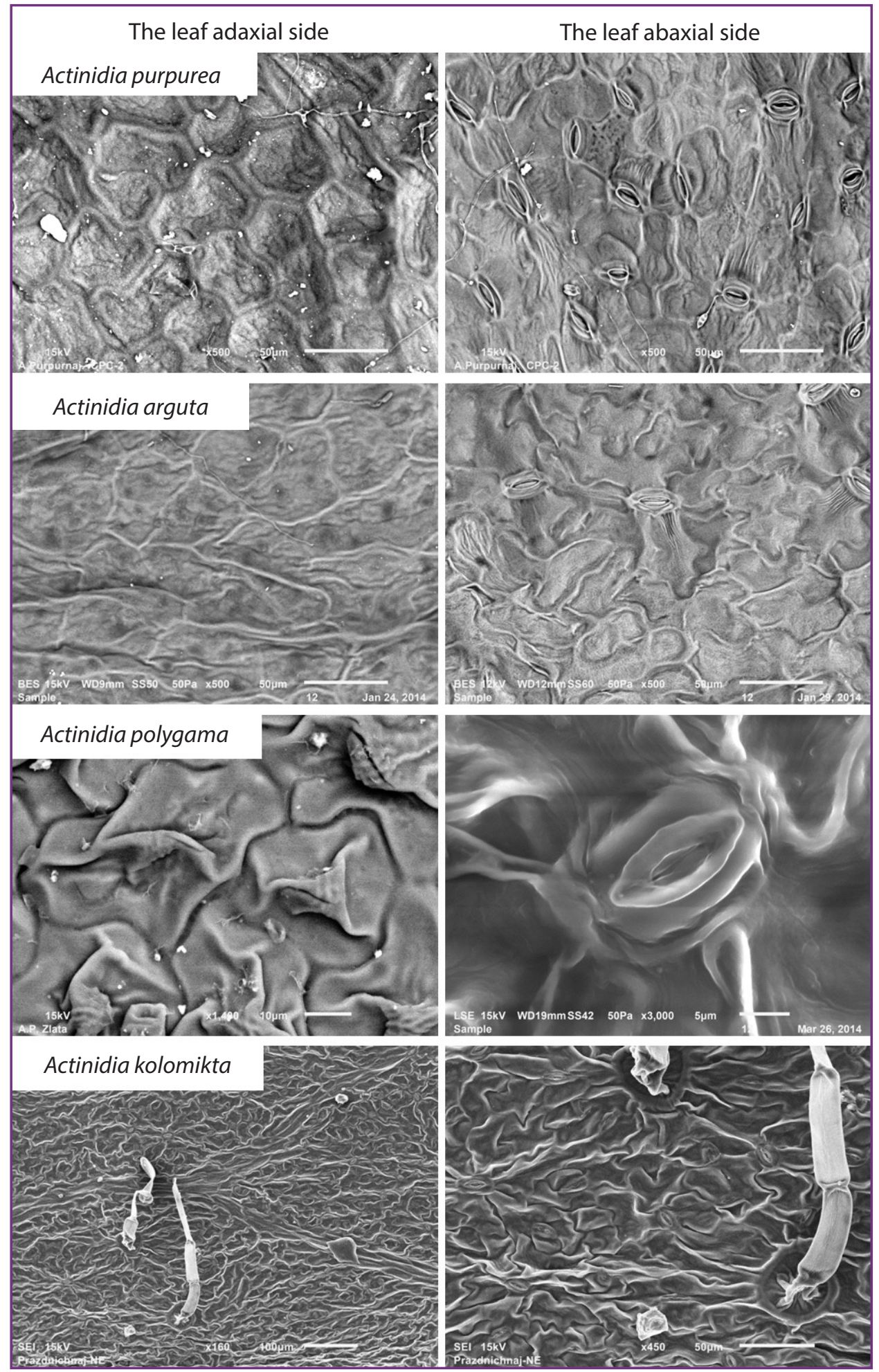

Figure 1

The morphological peculiarities of actinidia leaves surface 
Table 1 The breeds morphometric features of different Actinidia spp., $\overline{\mathbf{x}}(2013-2015)$

\begin{tabular}{|c|c|c|c|c|c|c|}
\hline \multirow[t]{2}{*}{ Species, cultivars } & \multicolumn{3}{|c|}{ Leaf adaxial side } & \multicolumn{3}{|c|}{ Leaf abaxial side } \\
\hline & $\begin{array}{c}\text { cells } \\
\text { perimeter, } \\
\mu \mathrm{m}\end{array}$ & cells I/h & $\begin{array}{c}\text { cells } \\
\text { perimeter, } \\
\mu \mathrm{m}\end{array}$ & cells $/ / h$ & $\begin{array}{l}\text { Stomatos } \\
\quad \mathrm{L}, \mu \mathrm{m}\end{array}$ & $\begin{array}{l}\text { stomatal } \\
\text { number, } \\
\text { pcs/mm² }\end{array}$ \\
\hline \multicolumn{7}{|c|}{ Actinidia kolomikta } \\
\hline Nadezhda $q$ & $100.87 \pm 9.12$ & $2.09 \pm 0.87$ & $61.75 \pm 5.12$ & $2.16 \pm 1.84$ & $12.84 \pm 2.89$ & $296.42 \pm 1.8$ \\
\hline Prelestnaya $q$ & $117.94 \pm 22.17$ & $2.01 \pm 0.75$ & $114.12 \pm 6.71$ & $1.98 \pm 2.01$ & $13.96 \pm 4.21$ & $141.87 \pm 4.1$ \\
\hline Prazdnichnaya $q$ & $138.77 \pm 14.13$ & $1.60 \pm 0.54$ & $121.56 \pm 14.8$ & $1.72 \pm 1.95$ & $10.71 \pm 3.47$ & $273.36 \pm 3.2$ \\
\hline Priusadebnaya $\uparrow$ & $160.69 \pm 12.11$ & $1.81 \pm 0.48$ & $225.08 \pm 6.24$ & $2.04 \pm 1.34$ & $16.96 \pm 1.84$ & $346.02 \pm 3.4$ \\
\hline Pamiati Kolbasinoi $\bigcirc$ & $190.45 \pm 13.11$ & $2.06 \pm 0.81$ & $136.52 \pm 7.02$ & $1.78 \pm 2.14$ & $18.68 \pm 0.52$ & $166.95 \pm 3.4$ \\
\hline Sestra $q$ & $112.88 \pm 10.24$ & $2.05 \pm 0.45$ & $97.43 \pm 6.14$ & $2.27 \pm 2.01$ & $12.07 \pm 2.11$ & $295.8 \pm 2.2$ \\
\hline Sakhar Medovich $\hat{\jmath}$ & $139.42 \pm 14.35$ & $2.12 \pm 0.77$ & $179.3 \pm 4.32$ & $1.45 \pm 2.23$ & $13.11 \pm 2.45$ & $415.02 \pm 2.1$ \\
\hline$\overline{\mathbf{x}}$ & 137.28 & 1.96 & 133.68 & 1.59 & 14.05 & 276.48 \\
\hline \multicolumn{7}{|c|}{ Actinidia polygama } \\
\hline Zlata + & $151.1 \pm 12.31$ & $2.08 \pm 1.0$ & * & * & $11.58 \pm 3.11$ & $307.61 \pm 3.1$ \\
\hline Lesnaya $q$ & $148.5 \pm 11.21$ & $1.46 \pm 0.54$ & $115.1 \pm 4.11$ & $2.23 \pm 0.4$ & $9.92 \pm 3.14$ & $242.24 \pm 1,2$ \\
\hline Perchik & $137.7 \pm 13.21$ & $0.67 \pm 0.98$ & * & * & $9.63 \pm 4.11$ & $259.18 \pm 2.0$ \\
\hline Solntselikaya $q$ & $121.8 \pm 8.98$ & $1.98 \pm 1.11$ & * & * & $8.69 \pm 1.7$ & $242.21 \pm 1.8$ \\
\hline Aurel $\hat{\sigma}$ & $97.5 \pm 10.20$ & $1.39 \pm 0.87$ & * & * & $11.79 \pm 4.05$ & $268.81 \pm 3.1$ \\
\hline Blondin $\hat{\sigma}$ & $88.8 \pm 9.18$ & $0.60 \pm 0.78$ & * & * & $8.11 \pm 2.1$ & $224.91 \pm 2.4$ \\
\hline Brunet $\lambda$ & $138.45 \pm 10.12$ & $2.13 \pm 2.04$ & * & * & $8.41 \pm 2.11$ & $466.95 \pm 3.4$ \\
\hline$\overline{\mathbf{x}}$ & 126.26 & 1.47 & * & * & 9.73 & 287.84 \\
\hline \multicolumn{7}{|c|}{ Actinidia arguta } \\
\hline Doch' Zei & $162.70 \pm 9.18$ & $2.45 \pm 0.64$ & * & * & $13.78 \pm 5.8$ & $237.89 \pm 1.7$ \\
\hline Zolotaya Kosa $q$ & $139.14 \pm 8.54$ & $1.38 \pm 0.51$ & * & * & $16.21 \pm 2.84$ & $222.03 \pm 6.0$ \\
\hline Syn Zei $\precsim$ & $130.93 \pm 8.15$ & $1.51 \pm 0.54$ & * & * & $16.63 \pm 3.11$ & $131.92 \pm 8.1$ \\
\hline$\overline{\mathbf{x}}$ & 144.23 & 1.78 & * & * & 15.54 & 197.28 \\
\hline \multicolumn{7}{|c|}{ Actinidia purpurea } \\
\hline SPS-2 & 171.94 & 1.77 & 115.98 & 1.54 & $16.64 \pm 2.12$ & $276.82 \pm 1.4$ \\
\hline Konsul $\lesssim$ & 142.47 & 1.68 & 115.23 & 1.47 & $15.58 \pm 1.87$ & $276.82 \pm 1.2$ \\
\hline$\overline{\mathbf{x}}$ & 157.21 & 1.73 & 115.61 & 1.51 & 16.11 & 276.82 \\
\hline
\end{tabular}

* to determine the perimeter abaxial side cells is difficult due to the solid waxy layer

The largest medium perimeter is characteristic for Actinidia purpurea and Actinidia arguta (157.12 and $144.3 \mu \mathrm{m})$. The ratio of the cells length to their width at Actinidia kolomikta, Actinidia arguta, 
Actinidia purpurea and Actinidia polygama is $1.96 ; 1.78 ; 1.73$ and 1.47 correspondingly. The perimeter and the ratio of the leaves length to their width of Actinidia kolomikta leaf abaxial side is close to the adaxial side ones.

To determine the perimeter of Actinidia arguta, Actinidia purpurea and Actinidia polygama abaxial side cells is difficult due to the solid waxy layer. The minimum stomatal number on $1 \mathrm{~mm}^{2}$ is characteristic for Actinidia arguta $\left(197.3 \mathrm{pcs} / \mathrm{mm}^{2}\right)$. For the rest species the stomatal number is within $276.5-287.8\left(\mathrm{pcs} / \mathrm{mm}^{2}\right)$. The minimum stomatal length is characteristic for Actinidia polygama $(9.73 \mu \mathrm{m})$, the maximal one is at Actinidia arguta and Actinidia purpurea.

\section{Conclusions}

In Actinidia kolomikta, Actinidia arguta, Actinidia purpurea and Actinidia polygama cultivars, the cells of the adaxial side of the leaf have a similarly irregularly shape: polygonal, elongated, less often oval. Short trichomes were found on both sides of the leaf along the central vein. For Actinidia kolomikta in comparison with the rest species more lengthened cells form of the leaf adaxial side $(I / h=1.96)$ is characteristic. In majority cases the substantial differences in the stomatal number between male and female forms are not found. The stomata are located on the adaxial side of the leaf. They differ in size: the varieties of species Actinidia arguta and Actinidia purpurea - the largest - 13.8-16.6 $\mu \mathrm{m}$, from Actinidia polygama stomata minimum length - $9.73 \mu \mathrm{m}$. The minimum stomatal length is characteristic for Actinidia polygama $(9.73 \mu \mathrm{m})$, the maximal one is at Actinidia arguta and Actinidia purpurea.

\section{References}

Барыкина, Р.П. и др. 2004. Справочник по ботанической микротехнике. Основы и методы. М.: Изд-во МГУ. 312 c.

Бисерова, Н.М. 2013. Методы визуализачии биологических ультраструктур. М.: Изд-во МГУ. 62 с.

Васильев, А. Е., Воронин, И.С., Еленевский, А.Г., Серебрякова, Т.И. 1978. Ботаника. Анатомия и морфология растений. М.: Просвещение. 480 с.

Козак, Н.В. 2015. Генетическая коллекция актинидии. Генетические коллекции плодовых, ягодных, редких и иветочно-декоративных культур ФГБНУ ВСТИСП (дескриптор). М.: ФГБНУ ВСТИСП, c.41-48.

Козак, Н.В., Колбасина, Э.И. 2014. О ценных коллекционных образцах актинидии аргута. Садоводство и виноградарство, № 3, с. 6-11.

Мотылева, С.М., Мертвищева, М.Е., Козак, Н.В. 2014. О морфолого-биохимических особенностях сортов актинидии коломикта Actinidia kolomikta (Maxim. ex Rupr.). Maтериалы V научной конференции «енетика, физиология и селекция растений». Молдова, Кишинев, с. 281-285.

Паутов, А.А., Яковлева, О.В., Колодяжный, С.Ф. 2002. Микрорельеф поверхности листьев у Populus (Salicaceae). Ботанический журнал, № 1, с. 67-71. 